\title{
High performance bactericidal glass: evaluation of the particle size and silver nitrate concentration effect in ionic exchange process
}

\section{(Vidro bactericida de alto desempenho: avaliação do efeito do tamanho de partícula e da concentração de nitrato de prata no processo de troca iônica)}

\author{
Elton Mendes ${ }^{1}$, Erlon Mendes ${ }^{1}$, G. D. Savi ${ }^{1}$, E. Angioletto ${ }^{1}$, H. G. Riella ${ }^{2}$, M. A. Fiori ${ }^{2}$ \\ ${ }^{1}$ Universidade do Extremo Sul Catarinense, Departamento de Engenharia Química, Criciúma, SC, Brazil \\ ${ }^{2}$ Universidade Federal de Santa Catarina, Departamento de Engenharia Química, \\ Programa de Pós-Graduação em Engenharia Química, Florianópolis, SC, Brazil
}

\begin{abstract}
Antimicrobial materials have long been used as an effective means of reducing the risks posed to humans by fungi, bacteria and other microorganisms. These materials are essential in environments where cleanliness, comfort and hygiene are the predominant concerns. This work presents preliminary results for a bactericidal vitreous material that is produced by the incorporation of a silver ionic specimen through ionic exchange reactions. Powdered glass was submitted to ionic exchange in an ionic medium containing $\mathrm{AgNO}_{3}$ as silver ions source. Different $\mathrm{AgNO}_{3}$ concentrations in ionic medium and different particle sizes of the glass were used in the samples development. Microbiological analysis of the samples was made by disk diffusion method in the Escherichia coli and Staphylococcus aureus bacterium species. Samples were still submitted to SEM-EDS, atomic absorption and X-ray diffraction techniques. Results showed that the bactericidal effect was dependent on $\mathrm{AgNO}_{3}$ concentration in the ionic exchange medium, but was not dependent on the particle size of the glass.
\end{abstract}

Keywords: ionic exchange, antimicrobial materials, oligodynamic effect, bactericidal glasses.

\section{Resumo}

Os materiais antimicrobianos têm sido amplamente empregados como um meio eficaz de reduzir os riscos proporcionados aos seres humanos por fungos, bactérias e outros microrganismos. Estes materiais são essenciais em ambientes onde predominam a limpeza, o conforto e a higiene. Este estudo apresenta resultados preliminares do desenvolvimento de um material vitreo com propriedade bactericida, obtido pela incorporação de espécies ionicas de prata, através de reações de troca ionica. O vidro em pó foi submetido à troca iônica em um meio iônico contendo $\mathrm{AgNO}_{3}$ como fonte de ions de prata. Diferentes concentrações de $\mathrm{AgNO}_{3}$ no meio iônico e diferentes tamanhos de partícula do vidro foram utilizados no desenvolvimento das amostras. A análise microbiológica das amostras foi realizada empregando o método de disco-difusão para as espécies de bactéria Escherichia coli e Staphylococcus aureus. As amostras também foram submetidas à caracterização pelas técnicas microscopia eletrônica de varredura, espectroscopia de energia dispersiva de raios $X$, espectroscopia de absorção atômica e por difração de raios X. Os resultados mostraram que o efeito bactericida foi dependente da concentração de $\mathrm{AgNO}_{3}$ no meio iônico, mas não foi dependente do tamanho de partícula do vidro.

Palavras-chave: troca iônica, materiais antimicrobianos, efeito oligodinâmico, vidros bactericidas.

\section{INTRODUCTION}

Due to the risk to human life offered by the action of bacteria, fungi and other pathogenic microorganisms, demand has been increasing for materials that guarantee the purity, comfort and hygiene of human environments. This need is more prevalent in homes and industrial settings where such microorganisms are more actively controlled. In this context, the development and use of biocidal materials is an efficient way to handle risk situations. In recent years many works with biocidal materials and additives with applications in polymeric and ceramic materials or in other material classes were developed [1-4]. Many works present studies regarding biocidal additive efficiency, methodologies for the production of bactericidal and fungicidal materials, and the optimization of biocidal properties [5]. In particular, the development of a biocidal additive is very interesting to industries. In additive form, these compounds can be used in order to bolster other materials biocidal characteristics. Some studies involve applications of biocidal additives in the packages for foods [6] and for plastics [7, 8]. These studies involve organics and mineral compounds with microbiological properties. So, the biocidal materials have had many studies to its application as biocidal additive.

The biocidal properties of silver ions have been known since ancient times, leading to their use as a bactericide in catheters, the treatment of burn wounds, and dental work. However, residual silver ions in treated water may adversely affect human health [9-11]. Compounds containing silver ions specimens with bactericidal and fungicidal properties 
have proportional effect to the ion concentration due to the oligodynamic effect. The oligodynamic aspect is a toxic effect of metals ions on living cells, algae, fungus, bacteria, virus or other microorganisms, even in relatively low concentrations. This antimicrobial effect is shown for ions: mercury, silver, copper, iron, lead, zinc, bismuth, gold, aluminum and other metals. Especially heavy metals exhibit this effect [12-15]. The antimicrobial mechanisms of free silver ions have been evaluated and a number of targets have been identified. Silver ions form insoluble compounds with sulfhydryl groups in the cell wall of bacteria and fungi, which are essential components of enzymes responsible for transmembranous energy metabolism and electrolyte transport. Silver ions block the respiratory chain of bacteria in the cytochrome oxidase and NADHsuccinate-dehydrogenase region. Silver ions enter the cell and bind to bacterial DNA. Intercalation of silver leads to an increased stability of the double helix and prevention of splicing. Therefore, no further proliferation occurs [16, 17]. Ionic silver specimens can be incorporated in glasses or natural clays by ionic exchange process with different concentrations depending on matrix type and on the ionic exchange parameter process utilized. The ionic exchange is an adsorption operation in which the sorbent performs the exchange of a solute for another. Aluminosilicates, such as glass and zeolites, can be used as effective and/or selective ion exchanger. The ion exchange process employed in glass and/or mineral clays provides unconventional properties to these materials, depending on the ion to be incorporated in the network, such as staining, electrical conductivity and biocidal effect $[18,19]$.

The adsorption of solutes by porous adsorbents involves three main steps: i) transfer of mass from the liquid phase to the porous surface of the adsorbent; ii) diffusion within the porous particle; and iii) adsorption on the inner surface of the pores of the adsorbent [20,21]. Theoretical models of equilibrium isotherms for adsorption processes can be applied to ion exchange reactions. In 1906, Freundlich developed the first model for isothermal adsorption. The Freundlich isotherm describes the multilayer adsorption with interaction between the adsorbed molecules. The model is applicable to adsorption on heterogeneous surfaces by a uniform energy distribution and reversible adsorption. The Freundlich model implies that the adsorption energy decays exponentially as the centers available for adsorption are occupied in the adsorbent [22]. The Langmuir model (1918) quantitatively describes the formation of an adsorbate monolayer on the surface of the adsorbent. At this point, the adsorption process closes. The Langmuir adsorption isotherm is based on the following hypotheses: 1) monolayer adsorption; 2) adsorption occurs at specific homogeneous sites in the adsorbent; 3) only one solute occupies one site, no adsorption can occur at the occupied site; 4) the adsorption energy is constant and does not depend on the degree of occupation of the active centers of the adsorbent; 5) the intermolecular attraction force decreases rapidly with the distance; 6) the adsorbent has a finite capacity for the solute; 7) all sites are identical and have equivalent energy; 8) the adsorbent is structurally homogeneous; 9) there is no interaction between adsorbed molecules on neighboring sites [22].

Ionic exchange involving oligodynamic specimens is favored by the presence of sodium in the glass or clay structure, which, in the case of $\mathrm{Ag}^{+}$and $\mathrm{Na}^{+}$ions, is due to their similar ionic radii and equivalent valence states. The other factors that influence the efficiency of ionic exchange are the reactive area and the porosity. For large diameter particles, the reactive area is only the particle surface, while its interior remains inert. The fixation and retention of solute by a sorbent particle are given by the pores on its surface. The particle outer surface alone is not able to meet the needs of the sorption process, whether analyzed as a phase, or as a slurry of finely powdered material. Thus, ionic exchange is facilitated by the greater porosity of the ion exchanger [23]. The biocidal properties of clays or glasses depend on the presence of oligodynamic specimens in their structure. The percentage of ionic silver in a material structure is a fundamental factor in determining the magnitude of its bactericidal activity. The bactericidal efficiency of glasses or clays submitted to ionic exchange with silver ions is proportional to the percentage of ionic silver incorporated by the exchange process [24]. Silver ionic species have more intense antimicrobial activity than other metals. Silver ions have good selective toxicity, being toxic to several pathogenic microorganisms and, in low concentrations, nontoxic to humans. In addition, silver ions do not promote bacterial resistance. $\mathrm{Ag}^{+}$ions loaded onto solid supports are slowly released in the environment, maintaining silver concentration in the medium at non-toxic levels to humans and promoting bactericidal activity for a long period of time $[19,25]$.

This study evaluates the effect of particle size and silver nitrate concentration in ionic medium on bactericidal activity. An ionic medium containing silver nitrate $\left(\mathrm{AgNO}_{3}\right)$ was used to develop an ionic exchange process between sodium ions already present in the glass and the bactericidal silver ions present in the ionic medium. Samples were fabricated, varying the particle size of the powdered glass and the silver nitrate concentration in the ionic medium while keeping the temperature constant. After ionic exchange process, the glass samples were submitted to microbiological analysis, SEM-EDS, atomic absorption and X-ray diffraction techniques. The antimicrobial activity of the samples was evaluated by disk diffusion method for the Escherichia coli and Staphylococcus aureus bacterium species. The experimental project was conducted in $2^{\mathrm{k}}$ factorial designs with two factors.

\section{EXPERIMENTAL PROCEDURE}

Glass development: presence of sodium species in the vitreous material structure favors the ionic exchange reaction with silver ions. Thus, the glass used in this work must contain a high sodium concentration. The glass was 
Table I - Glass formula (wt $\%$ ) according to [13].

[Tabela I - Composição do vidro (\% em massa) de acordo com [13].]

\begin{tabular}{llll}
\hline $\mathrm{Al}_{2} \mathrm{O}_{3}$ & $\mathrm{SiO}_{2}$ & $\mathrm{Li}_{2} \mathrm{O}$ & $\mathrm{Na}_{2} \mathrm{O}$ \\
\hline 3.00 & 72.00 & 5.00 & 20.00 \\
\hline
\end{tabular}

prepared following the composition and methodology developed in [2]. The composition is provided in Table I. The raw materials were melted at $850{ }^{\circ} \mathrm{C}$ during $30 \mathrm{~min}$ with a heating rate of $10{ }^{\circ} \mathrm{C} / \mathrm{min}$, then at $1450{ }^{\circ} \mathrm{C}$ during $120 \mathrm{~min}$ at the same heating rate. In the sequence, the glass material was crushed in different particle sizes. Since it is known that the particle size affects the exchange area, three different mean particle sizes $(9.46,28.89$ and $51.60 \mu \mathrm{m}$, as determined by laser granulometric analysis) were chosen. The effect of this variation in size on the ionic exchange reaction was then evaluated according to $2^{\mathrm{k}}$ factorial design.

Ionic exchange treatment: the ion exchange can be represented by a reversible reaction involving chemically equivalent amounts [26]. The ion exchange mechanism for the chemical species involved occurred according to:

$\mathrm{Ag}^{+}{ }_{\text {(solution) }}+\mathrm{Na}^{+}{ }_{\text {(adsorbent) }} \leftrightarrow \mathrm{Ag}^{+}{ }_{\text {(adsorbent) }}+\mathrm{Na}_{\text {(solution) }}^{+}$

The ionic exchange process was performed utilizing powdered glass in an ionic medium containing $\mathrm{AgNO}_{3}$ (Cennabras, $99.5 \%$ purity) as the silver source and $\mathrm{NaNO}_{3}$ (Dinâmica, 99.0\% purity) as the melted medium. The powdered glass was immersed in the ionic medium and heated at $430{ }^{\circ} \mathrm{C}$ for over $4 \mathrm{~h}$ in a muffle oven. This process was repeated for different ionic media, maintaining a constant $\mathrm{NaNO}_{3}$ concentration but varying the $\mathrm{AgNO}_{3}$ concentration between 2, 6 and $10 \mathrm{wt} \%$, according to the $2^{\mathrm{k}}$ factorial design. The powdered glass was immersed into the ionic medium and submitted to $430{ }^{\circ} \mathrm{C}$ over $4 \mathrm{~h}$ in a muffle oven. This process was performed in different ionic media, maintaining constant the $\mathrm{NaNO}_{3}$ concentration but varying $\mathrm{AgNO}_{3}$ concentration. After the ionic exchange treatment, the samples were washed and kept in deionized water for two days. This procedure was used to dissolve the sodium residues incorporated on the glass surfaces during the ionic exchange process. The samples were then dried in an oven at $70{ }^{\circ} \mathrm{C}$ and crushed again to ungroup the particles. The parameters and concentrations used in this study followed strictly the procedures described in [2].

Microbiological tests: bactericidal activity of the samples was evaluated using the disk diffusion method. The Escherichia coli (ATCC 25922) and Staphylococcus aureus (ATCC 6538) bacterium species were inoculated into MacConkey and Mueller Hinton agar, respectively. The tests were conducted in Petri dishes containing three wells with 6 $\mathrm{mm}$ in diameter. To each well $0.035( \pm 0.001) \mathrm{g}$ of powdered glass was placed. Then, $10 \mu \mathrm{L}$ of sterile water were added into each well containing the material. Each sample was placed in individual Petri dish in triplicate. All tests were conducted at $37^{\circ} \mathrm{C}$ and the microorganisms were submitted to a $24 \mathrm{~h}$ incubation period. For all samples, microbiological tests were carried out to evaluate the influence of ionic medium and particle size on the production of a biocidal glass. In order to evaluate the bactericidal action in the agar well diffusion test, the bactericidal action areas (total and sample areas) were calculated as circles (Fig. 1). The Eq. B was used to calculate the bactericidal areas:

$$
A_{b a c}=A_{e x}-A_{\text {in }}
$$

where, $A_{b a c}$ is the bactericidal area and represents the bactericidal action, $\mathrm{A}_{\mathrm{ex}}$ is the death area of microorganism, and $A_{\text {in }}$ the sample area [2].

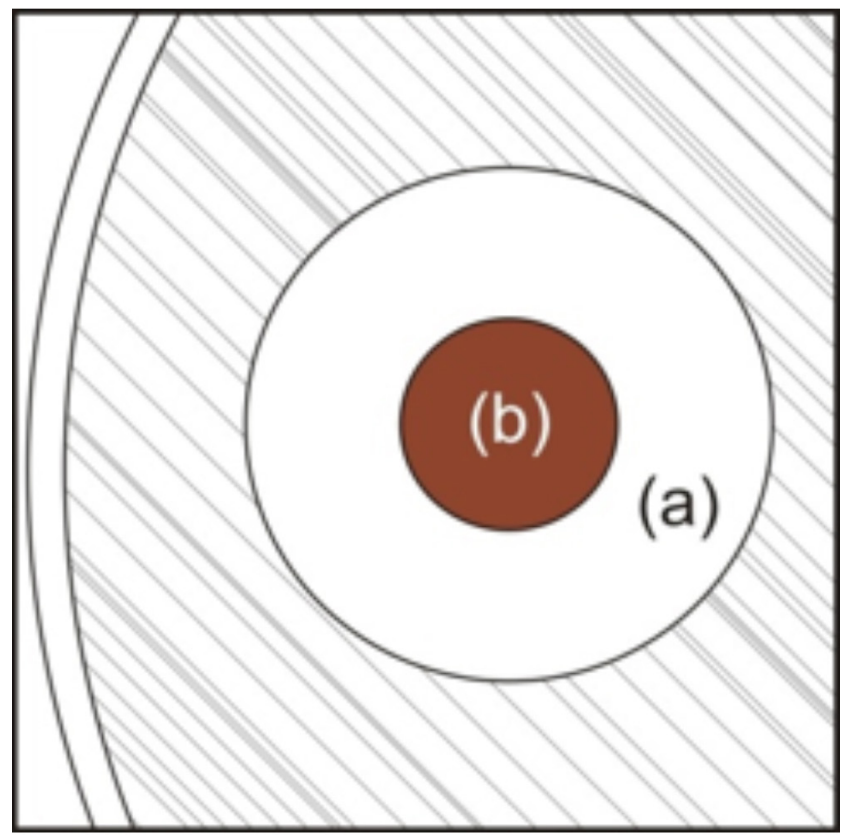

Figure 1: Model considered for evaluating the bactericide areas: a) bactericide area; and b) sample area.

[Figura 1: Modelo considerado para avaliar as áreas bactericidas: a) área bactericida; e b) área da amostra.]

Analysis of silver incorporation in powdered glass samples: after the ionic exchange process, the glass samples were submitted to microbiological analysis, SEM-EDS, atomic absorption and X-ray diffraction techniques. X-ray diffraction technique was used in the glass before and after ionic exchange to analyze the changes in glass structure due to the silver ions incorporation. The samples were submitted to atomic absorption (AA) spectroscopy to determine the silver ion concentration into the glass matrix and to scanning electron microscopy - energy dispersive X-ray spectroscopy (SEM-EDS) analysis to confirm the presence of the silver specimens in the glass structure. The powder glass was not soluble in water. So, it was necessary to transfer the silver ions incorporated in the powder glass by ionic exchange to a solution to apply the AA analysis. The technique used for this purpose was the cation exchange. A salt widely used in this process, including the exchange with silver ions, is the barium chloride $\left(\mathrm{BaCl}_{2} \cdot 2 \mathrm{H}_{2} \mathrm{O}\right.$, Fmaia, $99.0 \%$ purity) 
[27]. The cation exchange processes on the powdered glass samples were performed with a $1.2 \mathrm{M}$ solution of barium chloride containing $5.0 \mathrm{~g}$ of glass sample. The system was kept under magnetic stirring for $4 \mathrm{~h}$. In the sequence, the cation exchange solution was submitted to vacuum filtration to separate the liquid phase containing silver. This procedure was repeated for each powdered glass sample, generating seven different solutions. Atomic absorption spectroscopy was used in these solutions and the appropriate calculations were made to determine the silver amount in each sample. The mass fraction of silver was determined utilizing the equation:

$$
\left[\mathrm{Ag}^{+}\right] \%=\frac{\left[\mathrm{Ag}^{+}\right]_{\mathrm{s}} \cdot \mathrm{V}_{\mathrm{s}} \cdot 100 \%}{\mathrm{~m}}
$$

where, $\left[\mathrm{Ag}^{+}\right] \%$ is the weight percent of the silver ion in the bactericidal glass sample, $\left[\mathrm{Ag}^{+}\right]_{\mathrm{s}}$ is the mass concentration per liter in the cation exchange solution, $\mathrm{V}_{\mathrm{s}}$ is the volume in liter of the cation exchange solution, and $m$ the mass of the bactericidal glass sample submitted to cation exchange process. All experimental project was conducted in $2^{\mathrm{k}}$ factorial design with two factors, and the particle size of the powder glass and the silver nitrate concentration in the ionic medium were the independent variables.

\section{RESULTS AND DISCUSSION}

Fig. 2 shows granulometric distribution curves for glass ground for three different grinding times. The results showed particle sizes of $51.60,28.89$ and $9.46 \mu \mathrm{m}$ after 1,4 and 12 min of crushing, respectively. SEM images confirmed the different particle size values obtained for the different grinding times (Fig. 3).

$X R D$ results: Fig. 4 a shows a typical X-ray diffractogram for the powdered glass before the ionic exchange process. The diffractogram shows characteristic regions of the presence of amorphous phases in glass matrix in the range $(2 \theta) 10^{\circ}$ and $40^{\circ}$ and the absence of strong peaks characteristic of its crystalline structure. Fig. $4 \mathrm{~b}$ shows a diffractogram characteristic of a glassy material after the ionic exchange process in a medium containing $6 \mathrm{wt} \%$ concentration of silver nitrate. X-ray diffractogram shows the diffraction peaks characteristic of

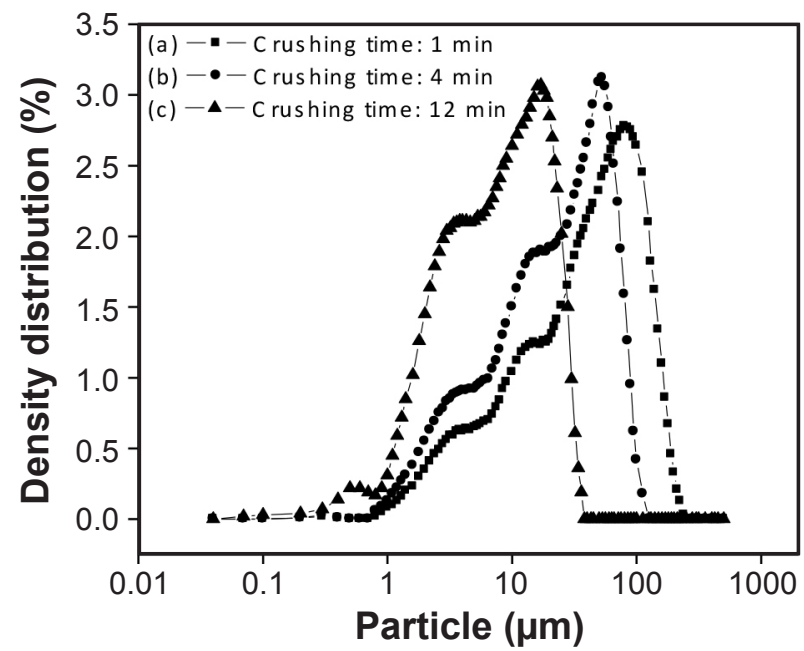

Figure 2: Particle size distributions for each glass obtained from different grinding times. Average particle size: (a) $51.6 \mu \mathrm{m}$; (b) $28.9 \mu \mathrm{m}$; and (c) $9.5 \mu \mathrm{m}$.

[Figura 2: Curvas de distribuição de tamanho de partícula obtidas para diferentes tempos de moagem do vidro. Tamanho médio de partícula obtido para: (a) 51,6 $\mathrm{m}$; (b) 28,9 $\mathrm{m}$; e (c) 9,5 $\mu \mathrm{m}$.]

crystalline structures containing silver species in the glass matrix. Diffractogram analysis from the database (JCPDS) confirmed the presence of phases containing silver element

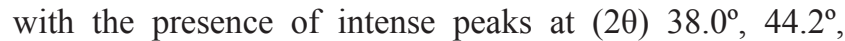
$64.5^{\circ}$ and $77.5^{\circ}$. The XRD procedure performed before and after the ionic exchange process confirmed the silver species incorporation in the glassy material structure. The peak magnitude or the peak area can be directly related to the volume of phases containing silver in the glass matrix. The greater the peak magnitude or its area, the greater the volume of phases containing silver species. Fig. $4 \mathrm{c}$ shows the comparison between two X-ray diffractograms obtained from the samples produced according to the experiments 1 and 3 of the experimental design, with fixed silver nitrate concentration in the ionic exchange medium and different particle size. The comparison between the characteristic peaks showed little variation in the peak magnitude and its area. This result is indicative of the presence of silver phases in the two ionic exchange experimental conditions, but with uncertain significance variation. The comparison between
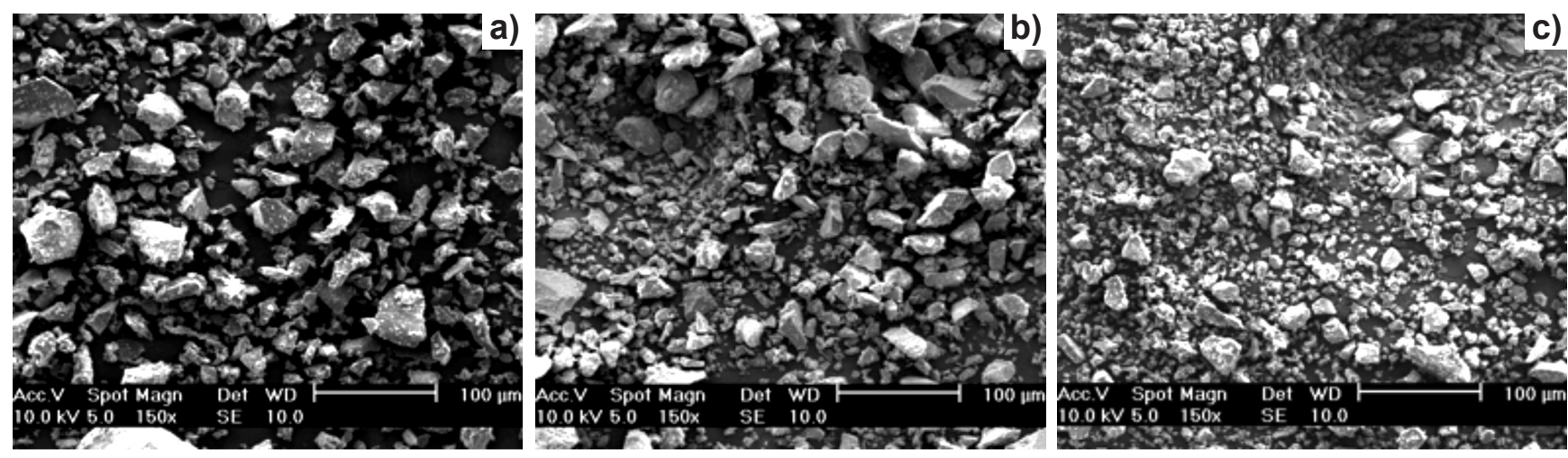

Figure 3: SEM images of powdered glass with different crushing time: (a) $1 \mathrm{~min}$; (b) $4 \mathrm{~min}$; and (c) $12 \mathrm{~min}$.

[Figura 3: Imagens de MEV das amostras de vidro em pó com diferentes tempos de moagem: (a) 1 min; (b) 4 min; e (c) 12 min.] 

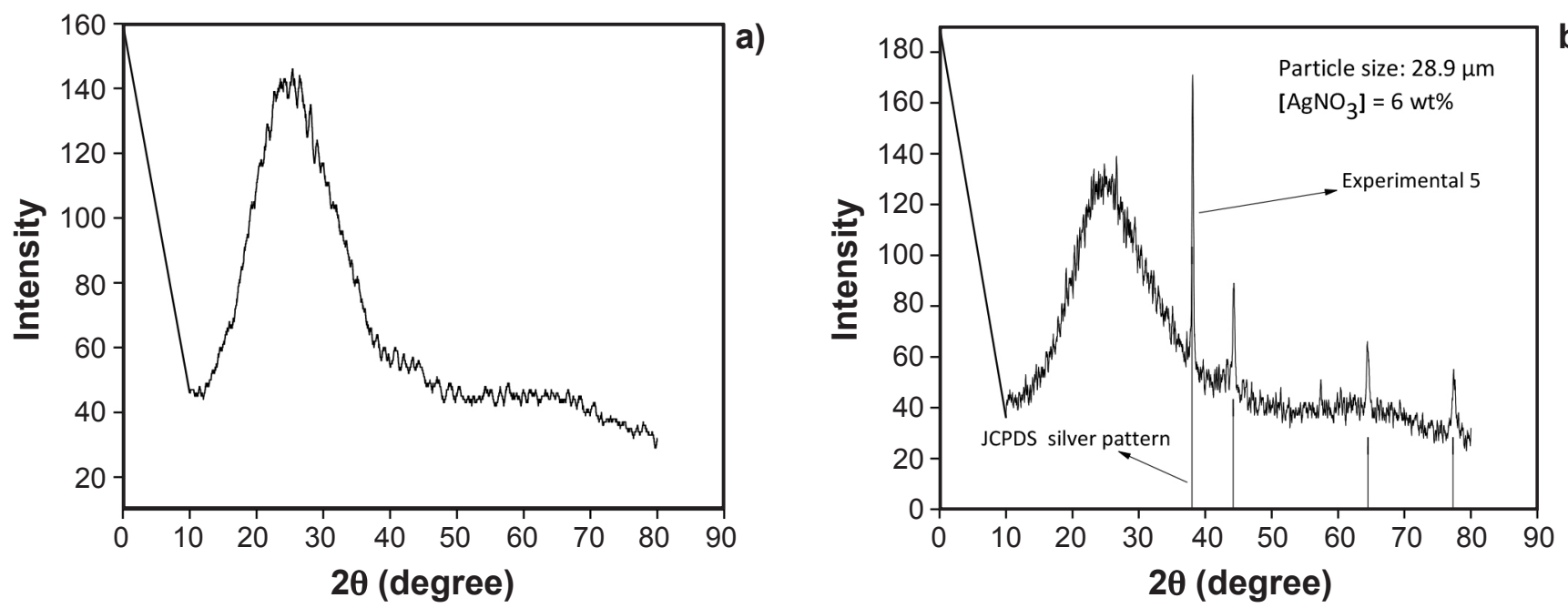

b)
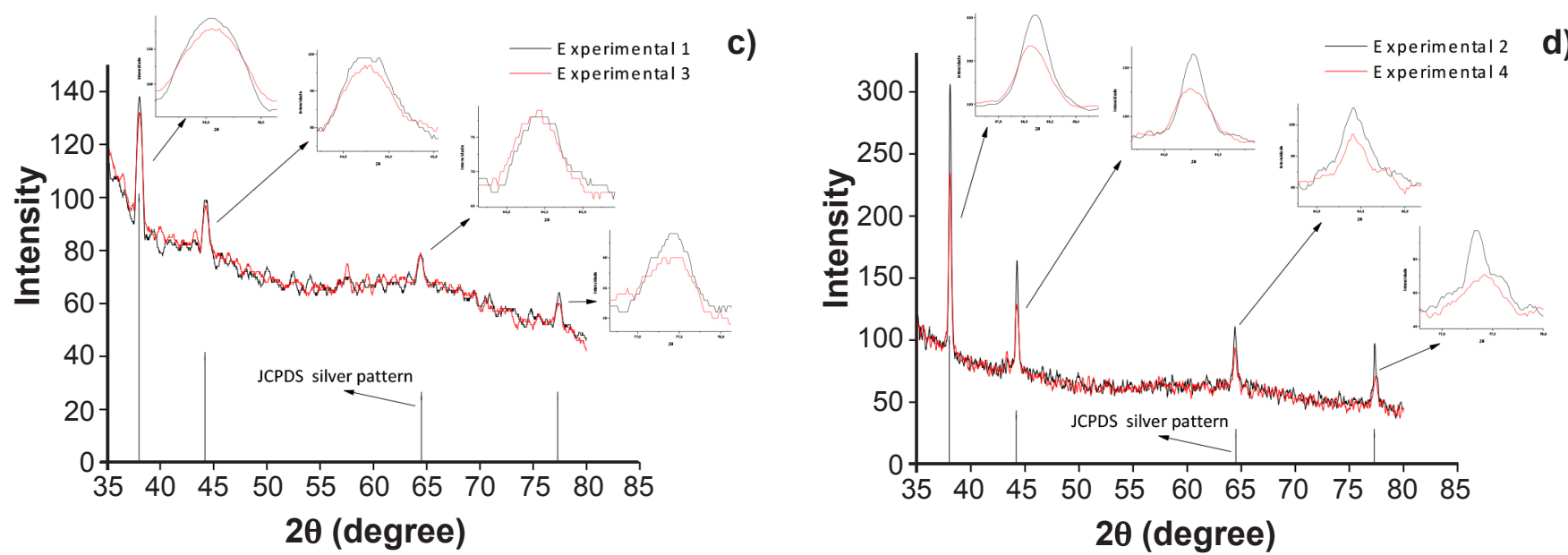

Figure 4: X-ray diffraction patterns of the powdered glass samples: (a) glass sample before ionic exchange; (b) glass sample after ionic exchange; (c) glass sample of the experiment 1 and 3; and (d) glass sample of the experiment 2 and 4.

[Figura 4: Difratogramas de raios $X$ das amostras de vidro em pó: (a) vidro antes da troca iônica; (b) vidro após a troca iônica; (c) amostras dos experimentos 1 e 3; e (d) amostras dos experimentos 2 e 4.$]$
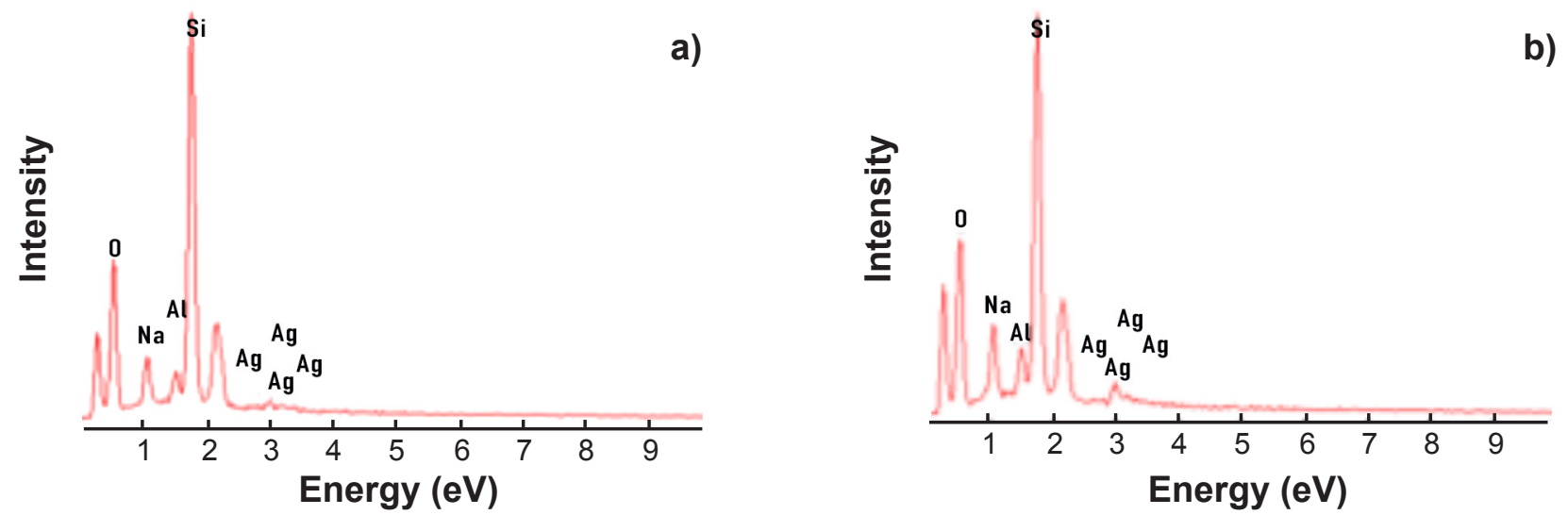

Figure 5: EDS spectra of the powdered glass samples: (a) sample 2; and (b) sample 4 (samples with the same $\mathrm{AgNO}_{3}$ percentage).

[Figura 5: Espectros de EDS das amostras de vidro em pó: (a) amostra 2; e (b) amostra 4 (amostras preparadas com o mesmo percentual de $\left.\left.\mathrm{AgNO}_{3}\right) \cdot\right]$

two diffractograms obtained from samples produced with the experimental procedures 2 and 4 is shown in Fig. $4 d$ considering the same particle size, but with the silver nitrate concentration in the ionic exchange medium of 2 and 10 
Table II - Silver concentration for each sample obtained by EDS.

[Tabela II - Concentração de prata para cada amostra, obtida por EDS.]

\begin{tabular}{|c|c|c|c|c|c|c|c|}
\hline \multirow{2}{*}{$\begin{array}{c}\text { Sample } \\
1\end{array}$} & \multirow{2}{*}{$\begin{array}{c}\text { Particle size } \\
(\mu \mathrm{m})\end{array}$} & \multirow{2}{*}{$\begin{array}{c}\mathrm{AgNO}_{3} \\
(\mathrm{wt} \%)\end{array}$} & \multicolumn{3}{|c|}{$\begin{array}{c}\text { Silver - Ag } \\
\text { concentration }(\mathrm{wt} \%)\end{array}$} & \multirow{2}{*}{$\begin{array}{c}\langle\mathrm{Ag}\rangle \\
(\mathrm{wt} \%)\end{array}$} & \multirow{2}{*}{$\frac{\sigma(\mathrm{wt} \%)}{0.6}$} \\
\hline & & & 0.93 & 2.05 & 1.99 & & \\
\hline 2 & 9.5 & 10 & 5.79 & 5.71 & 5.09 & 5.5 & 0.4 \\
\hline 3 & 51.6 & 2 & 2.90 & 2.64 & 2.28 & 2.6 & 0.3 \\
\hline 4 & 51.6 & 10 & 12.78 & 11.24 & 12.24 & 12.1 & 0.8 \\
\hline 5 & 28.9 & 6 & 9.21 & 7.34 & 7.85 & 8.1 & 1.0 \\
\hline 6 & 28.9 & 6 & 6.85 & 8.80 & 7.02 & 7.6 & 1.1 \\
\hline 7 & 28.9 & 6 & 5.51 & 6.18 & 7.91 & 6.5 & 1.2 \\
\hline
\end{tabular}

Table III - Variance analysis (ANOVA) to EDS results for powdered glass samples developed with different particle size and silver nitrate percentage.

[Tabela III - Análise da variância (ANOVA) para os resultados em EDS das amostras de vidro em pó desenvolvidas com diferentes tamanhos de partícula e percentuais de nitrato de prata.]

\begin{tabular}{cccccc}
\hline & $\mathrm{SS}$ & $\mathrm{df}$ & $\mathrm{MS}$ & $\mathrm{F}$ & $\mathrm{p}$ \\
\hline$*(1)$ Particle size $(\mu \mathrm{m})$ & $* 39.2992$ & $* 1$ & $* 39.2992$ & $* 18.5651$ & $* 0.000476$ \\
$*(2) \mathrm{AgNO}_{3}(\mathrm{wt} \%)$ & $* 133.7336$ & $* 1$ & $* 133.7336$ & $* 63.1762$ & $* 3.99 \mathrm{E}-07$ \\
$* 1$ by 2 & $* 23.5760$ & $* 1$ & $* 23.5760$ & $* 11.1374$ & $* 0.003903$ \\
Error & 35.9862 & 17 & 2.1168 & & \\
Total SS & 232.5951 & 20 & & & \\
\hline${ }_{\text {- significant variable. }}$ & & & & &
\end{tabular}

$\mathrm{wt} \%$. The results indicated the presence of phases containing silver element and large variation in the intensity and magnitude of characteristic peak areas. Such variations are significant and indicated a strong dependence of the volume of phases containing silver in the glass with the silver nitrate concentration in the ionic medium. The results showed that the ionic exchange process allowed the ionic silver incorporation as crystalline structure in the glass matrix.

EDS results: the elemental composition of the powdered glass samples was determined by use of an energy dispersive X-ray spectrometer. Fig. 5 presents typical EDS spectra for two samples of differing particle size showing the presence of elemental silver in the glass matrix after completion of the ionic exchange process. Table II shows the three values obtained for the silver concentrations in the glass for all particle sizes and silver nitrate concentrations according to the $2^{\mathrm{k}}$ factorial design. The EDS results showed an increase in the weight percentage of silver in the glass with an increase in particle size. This behavior was independent of the silver nitrate percentage present in the ionic medium. The results also showed the dependence of the weight percentage of silver in the glass on the silver nitrate concentration; an

Table IV - Silver ion concentration for each sample obtained by atomic absorption spectroscopy.

[Tabela IV - Concentração de ions de prata para cada amostra obtida por espectroscopia de absorção atômica.]

\begin{tabular}{ccccccccc}
\hline Sample & $\begin{array}{c}\text { Particle size } \\
(\mu \mathrm{m})\end{array}$ & $\begin{array}{c}\mathrm{AgNO}_{3} \\
(\mathrm{wt} \%)\end{array}$ & \multicolumn{2}{c}{$\begin{array}{c}\text { Silver ion }-\mathrm{Ag}^{+} \\
\text {concentration }(\mathrm{wt} \%)\end{array}$} & $\begin{array}{c}\left\langle\mathrm{Ag}^{+}\right\rangle \\
(\mathrm{wt} \%)\end{array}$ & $\sigma(\mathrm{wt} \%)$ \\
\cline { 1 - 2 } & 9.46 & 2.0 & & 0.00825 & 0.01722 & 0.0127 & 0.0063 \\
2 & 9.46 & 10.0 & 0.01979 & 0.02170 & 0.0207 & 0.0014 \\
3 & 51.60 & 2.0 & 0.01324 & 0.01501 & 0.0141 & 0.0013 \\
4 & 51.60 & 10.0 & 0.01641 & 0.01836 & 0.0174 & 0.0014 \\
5 & 28.89 & 6.0 & 0.01934 & 0.01557 & 0.0175 & 0.0027 \\
6 & 28.89 & 6.0 & 0.01677 & 0.01714 & 0.0170 & 0.0003 \\
7 & 28.89 & 6.0 & 0.01860 & 0.01752 & 0.0181 & 0.0008 \\
\hline
\end{tabular}


Table V - Variance analysis (ANOVA) to atomic absorption results for powdered glass samples developed with different particle size and silver nitrate percentage.

[Tabela V - Análise da variância (ANOVA) para os resultados de espectroscopia de absorção atômica das amostras de vidro em pó desenvolvidas com diferentes tamanhos de partícula e percentuais de nitrato de prata.]

\begin{tabular}{|c|c|c|c|c|c|}
\hline & SS & df & MS & $\mathrm{F}$ & $\mathrm{p}$ \\
\hline (1) Particle size $(\mu \mathrm{m})$ & 0.000002 & 1 & 0.000002 & 0.378824 & 0.551983 \\
\hline$*(2) \mathrm{AgNO}_{3}(\mathrm{wt} \%)$ & $* 0.000063$ & $* 1$ & $* 0.000063$ & *10.666612 & $* 0.008488$ \\
\hline 1 by 2 & 0.000011 & 1 & 0.000011 & 1.897634 & 0.198390 \\
\hline Error & 0.000059 & 10 & 0.000006 & & \\
\hline Total SS & 0.000137 & 13 & & & \\
\hline
\end{tabular}

increase in the silver nitrate concentration promoted an increase of the weight percentage of silver in the glass. Table III provides the variance analysis for the silver percentage incorporated into the glass structure as measured by EDS. The results confirmed the statistical significance of the particle size and silver nitrate concentration.

Atomic absorption results: values obtained in atomic absorption spectroscopy (Table IV) were statistically analyzed, and the particle size and silver nitrate concentration in the ionic medium for each sample were the independent variables while the silver ion concentration obtained by AA analysis was the dependent variable. Statistical analysis of the results generated Table V, which shows the variance analysis for silver ion concentration obtained by AA technique for glass samples processed with different parameters. The statistical results indicated that the silver ion concentration obtained by AA in the samples was related to the silver nitrate concentration in the ionic exchange medium, but it was not related to particle size. The variation of two parameters simultaneously did not interfere in the $\mathrm{Ag}^{+}$ concentration, without interconnection between the effect of the particle size and $\mathrm{AgNO}_{3}$ concentration in the ionic exchange medium in the silver ion concentration obtained by atomic absorption technique.

Microbiological results: Tables VI and VII show values for different processing conditions of biocide additive with different particle size and silver nitrate concentration in the ionic exchange medium in terms of antimicrobial activity in Escherichia coli and Staphylococcus aureus bacteria, respectively. The results showed the presence of bactericidal effects with low standard deviations and significant differences for the bactericidal response $\left(\mathrm{A}_{\mathrm{bac}}\right)$, depending on the parameters combination. The microbiological tests showed a large microbiological halo and an excellent bactericidal effect for the samples with silver ions for each microorganism type. In both tests, large death areas occurred for the bacteria and depend on bacterial type. However, for the Escherichia coli bacterium, the microbiological halo was smaller (Figs. 6 and 7). Jinu et al. [15] used the disc-diffusion method to evaluate the bactericidal properties of silver and copper nanoparticles. For the bacterium Escherichia coli and Staphylococcus aureus, the silver-glass samples had an antimicrobial effect similar to that of the silver nanoparticles prepared, however with a slightly lower intensity. The lower bactericidal activity of the silver-glass is due to the slow release of the silver oligodynamic ions, in relation to the ions released by the silver nanoparticles.

Fig. 6 shows the agar diffusion test results for samples with different particle size and silver nitrate concentration in the ionic medium utilizing Escherichia coli bacterium. Values obtained in agar diffusion test with Escherichia coli (Table VI) were statistically analyzed, and the particle

Table VI - Microbiological results for different particle size and silver nitrate percentage - Escherichia coli. [Tabela VI - Resultados microbiológicos para as amostras com diferentes tamanhos de partícula e diferentes percentuais de nitrato de prata no meio de troca iônica - Escherichia coli.]

\begin{tabular}{cccccccc}
\hline Sample & $\begin{array}{c}\text { Particle } \\
\text { size }(\mu \mathrm{m})\end{array}$ & $\begin{array}{c}\mathrm{AgNO}_{3} \\
(\mathrm{wt} \%)\end{array}$ & \multicolumn{2}{c}{$\begin{array}{c}\text { Bactericide area }-\mathrm{A}_{\mathrm{bac}} \\
\left(\mathrm{cm}^{2}\right)\end{array}$} & $\begin{array}{c}\left\langle\mathrm{A}_{\mathrm{bac}}\right\rangle \\
\left(\mathrm{cm}^{2}\right)\end{array}$ & $\begin{array}{c}\sigma \\
\left(\mathrm{cm}^{2}\right)\end{array}$ \\
\hline 1 & 9.46 & 2.0 & 0 & 0 & 0 & 0 & 0 \\
2 & 9.46 & 10.0 & 0.503 & 0.503 & 0.503 & 0.503 & 0.000 \\
3 & 51.60 & 2.0 & 0.503 & 0.503 & 0.503 & 0.503 & 0.000 \\
4 & 51.60 & 10.0 & 0.848 & 0.848 & 0.848 & 0.848 & 0.000 \\
5 & 28.89 & 6.0 & 0.220 & 0.220 & 0.220 & 0.220 & 0.000 \\
6 & 28.89 & 6.0 & 0.353 & 0.353 & 0.353 & 0.353 & 0.000 \\
7 & 28.89 & 6.0 & 0.503 & 0.503 & 0.503 & 0.503 & 0.000 \\
\hline
\end{tabular}


Table VII - Microbiological results for different particle size and silver nitrate percentage Staphylococcus aureus.

[Tabela VII - Resultados microbiológicos para as amostras com diferentes tamanhos de partícula e diferentes percentuais de nitrato de prata no meio de troca ionica - Staphylococcus aureus.]

\begin{tabular}{cccccccc}
\hline Sample & $\begin{array}{c}\text { Particle } \\
\text { size }(\mu \mathrm{m})\end{array}$ & $\begin{array}{c}\mathrm{AgNO}_{3} \\
(\mathrm{wt} \%)\end{array}$ & $\begin{array}{c}\text { Bactericide area }-A_{\text {bac }} \\
\left(\mathrm{cm}^{2}\right)\end{array}$ & $\begin{array}{c}\left\langle\mathrm{A}_{\text {bac }}\right\rangle \\
\left(\mathrm{cm}^{2}\right)\end{array}$ & $\begin{array}{c}\sigma \\
\left(\mathrm{cm}^{2}\right)\end{array}$ \\
\hline 1 & 9.46 & 2.0 & 0.220 & 0.220 & 0.220 & 0.220 & 0.000 \\
2 & 9.46 & 10.0 & 0.668 & 0.668 & 0.848 & 0.728 & 0.104 \\
3 & 51.60 & 2.0 & 0.503 & 0.503 & 0.503 & 0.503 & 0.000 \\
4 & 51.60 & 10.0 & 0.848 & 0.848 & 1.045 & 0.914 & 0.113 \\
5 & 28.89 & 6.0 & 0.848 & 0.848 & 0.848 & 0.848 & 0.000 \\
6 & 28.89 & 6.0 & 1.045 & 1.045 & 1.045 & 1.045 & 0.000 \\
7 & 28.89 & 6.0 & 1.045 & 1.045 & 0.848 & 0.979 & 0.113 \\
\hline
\end{tabular}
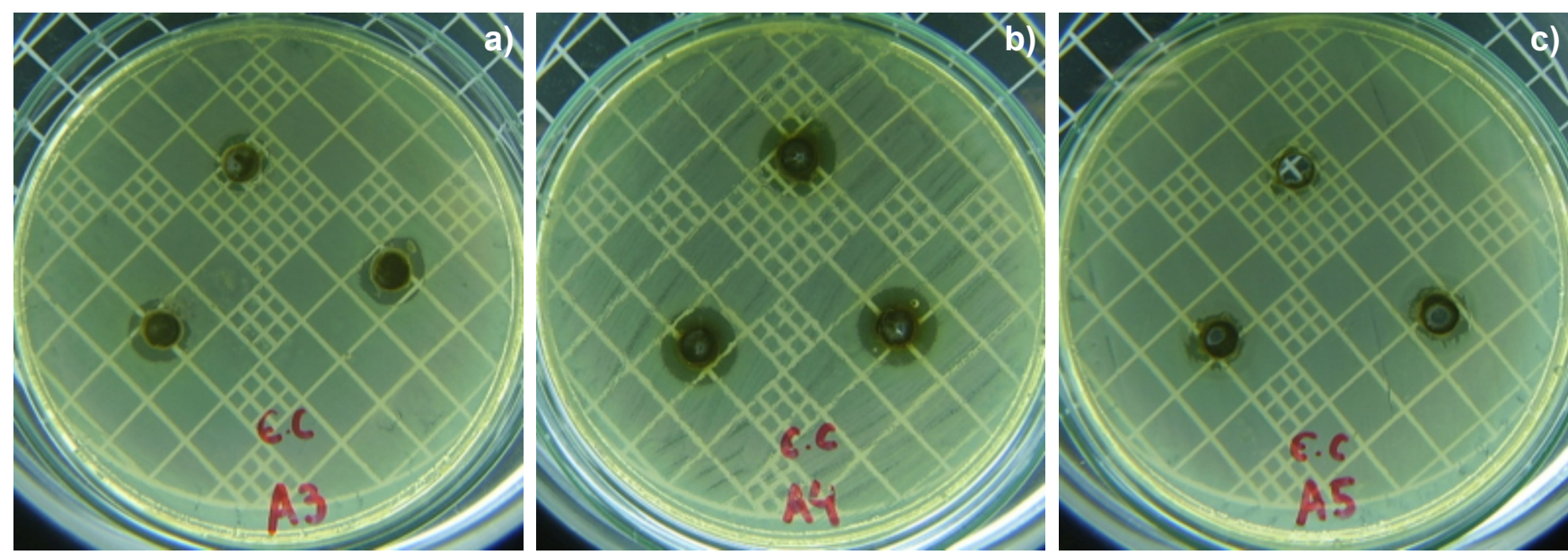

Figure 6: Microbiological results with Escherichia coli bacterium for different particle size and silver nitrate percentage: (a) sample 3; (b) sample 4; and (c) sample 5 - Table VI.

[Figura 6: Resultados microbiológicos em bactéria Escherichia coli para amostras com diferentes tamanhos de partícula e percentuais de nitrato de prata no meio de troca iônica: (a) amostra 3; (b) amostra 4; e (c) amostra 5 - Tabela VI.]
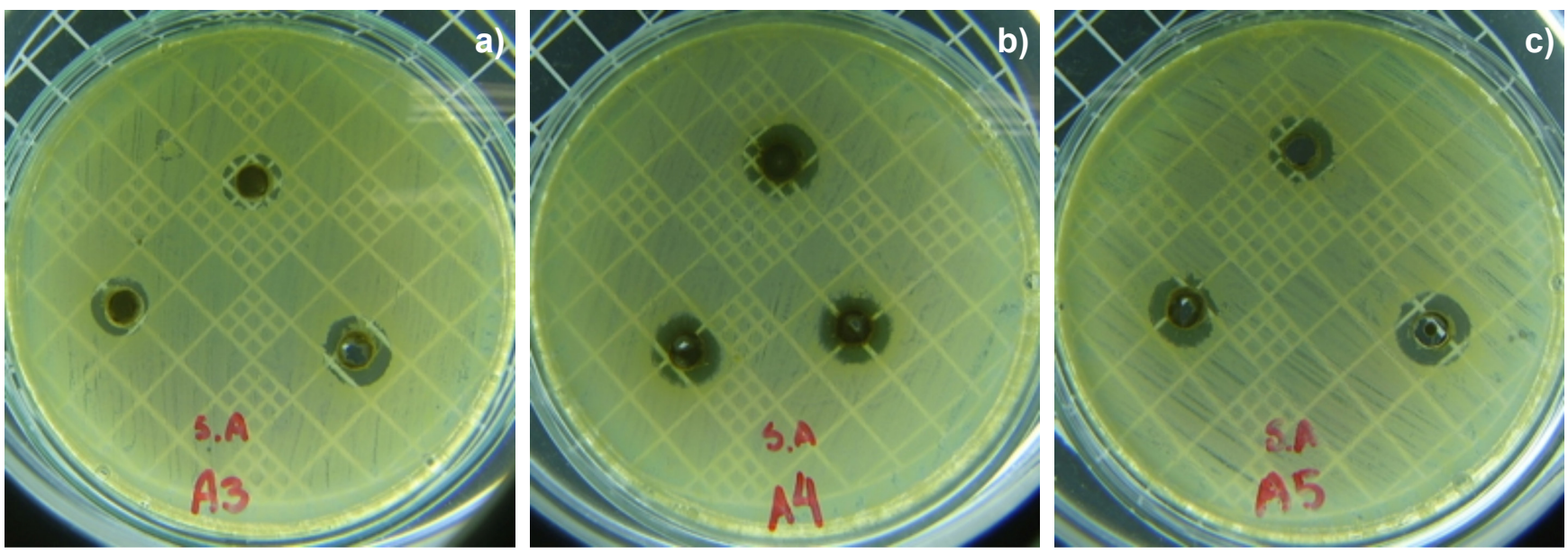

Figure 7: Microbiological results with Staphylococcus aureus bacterium for different particle size and silver nitrate percentage: (a) sample 3; (b) sample 4; and (c) sample 5 - Table VII.

[Figura 7: Resultados microbiológicos em bactéria Staphylococcus aureus para amostras com diferentes tamanhos de partícula e percentuais de nitrato de prata no meio de troca iônica: (a) amostra 3; (b) amostra 4; e (c) amostra 5 - Tabela VII.]

size and silver nitrate concentration in the ionic medium for each sample were the independent variables while the bactericidal activity observed in Escherichia coli bacterium was the dependent variable. Statistical analysis of the results 
Table VIII - Variance analysis (ANOVA) for microbiological results with Escherichia coli for powdered glass samples developed with different particle size and silver nitrate percentage. [Tabela VIII - Análise da variância (ANOVA) para os resultados microbiológicos com Escherichia coli para as amostras de pó de vidro desenvolvidas com diferentes tamanhos de partícula e diferentes percentuais de nitrato de prata no meio de troca iônica.]

\begin{tabular}{cccccc}
\hline & $\mathrm{SS}$ & $\mathrm{df}$ & $\mathrm{MS}$ & $\mathrm{F}$ & $\mathrm{p}$ \\
\hline (1) Particle size $(\mu \mathrm{m})$ & 0.0749 & 1 & 0.0749 & 0.0033 & 0.9547 \\
(2) $\mathrm{AgNO}_{3}(\mathrm{wt} \%)$ & 0.5396 & 1 & 0.5396 & 0.0239 & 0.8789 \\
1 by 2 & 0.0185 & 1 & 0.0185 & 0.0008 & 0.9775 \\
Error & 383.4157 & 17 & 22.554 & & \\
Total SS & 384.0487 & 20 & & & \\
\hline
\end{tabular}

Table IX - Variance analysis (ANOVA) for microbiological results with Staphylococcus aureus for powdered glass samples developed with different particle size and silver nitrate percentage. [Tabela IX - Análise da variância (ANOVA) para os resultados microbiológicos com Staphylococcus aureus para as amostras de pó de vidro desenvolvidas com diferentes tamanhos de particula e diferentes percentuais de nitrato de prata no meio de troca iônica.]

\begin{tabular}{cccccc}
\hline & $\mathrm{SS}$ & $\mathrm{df}$ & $\mathrm{MS}$ & $\mathrm{F}$ & $\mathrm{P}$ \\
\hline (1) Particle size $(\mu \mathrm{m})$ & 0.1318 & 1 & 0.1318 & 2.6171 & 0.1241 \\
$*(2) \mathrm{AgNO}_{3}(\mathrm{wt} \%)$ & $* 0.6333$ & $* 1$ & $* 0.6333$ & $* 12.5762$ & $* 0.0025$ \\
1 by 2 & 0.0070 & 1 & 0.0070 & 0.1397 & 0.7132 \\
Error & 0.8561 & 17 & 0.0504 & & \\
Total SS & 1.6282 & 20 & & & \\
\hline *- significant variable. & & & & &
\end{tabular}

generated Table VIII. Table VIII shows the variance analysis for the microbiological results with Escherichia coli for glass samples processed with different parameters. The statistical results indicated that no variable was significant for the area obtained in the agar diffusion test with Escherichia coli bacterium. While Staphylococcus aureus was a Grampositive bacterium, Escherichia coli was Gram-negative. Among the differences between these two kinds of bacterium, there is the resistance and sensitivity that each one has to antimicrobial materials [5]. Escherichia coli bacterium is less sensitive to the powdered glass bactericidal effect. Thus, a small variation in the silver nitrate concentration in the ionic medium would not be enough to change the bactericide area. However, this fact does not prove that the variation of the $\mathrm{AgNO}_{3}$ concentration in the ionic medium does not influence the biocidal effect of powdered glass in the Escherichia coli bacterium.

Fig. 7 shows the agar diffusion test results for samples with different particle size and silver nitrate concentration in the ionic medium utilizing Staphylococcus aureus. Values obtained in agar diffusion test with Staphylococcus aureus (Table VII) were statistically analyzed, and the particle size and silver nitrate concentration in the ionic medium for each sample were the independent variables while the bactericidal activity observed in Staphylococcus aureus bacterium was the dependent variable. Statistical analysis of the results generated Table IX, which shows the variance analysis for the microbiological results with Staphylococcus aureus for powdered glass samples processed with different parameters. The statistical results indicated that the area obtained in the agar diffusion test with Staphylococcus aureus bacterium was related to the silver nitrate concentration in the ionic exchange medium, but it was not related to particle size. The variation of two simultaneous parameters did not interfere in the bactericidal area, without interconnection between the effect of the particle size and $\mathrm{AgNO}_{3}$ concentration in the ionic exchange medium in the biocidal area obtained in Staphylococcus aureus.

\section{CONCLUSIONS}

The presence of silver in the doped glass structure was confirmed by the X-ray diffraction, EDS and atomic absorption spectroscopy techniques. The silver weight percent measured by EDS was larger than the silver weight percent measured by atomic absorption technique. This difference was because the silver specimens measured by AA technique were only the silver ionic species present in the glass structure. Samples containing silver ions showed bactericidal properties, with proportional effect to the ion concentration found in atomic absorption analysis. The values of the bactericidal area obtained by the disk-diffusion method with the Escherichia coli and Staphylococcus aureus bacteria were considered excellent. The microbiological results indicated a higher toxicity of $\mathrm{Ag}^{+}$ions to the Staphylococcus aureus (Gram-negative) bacterium in 
relation to Escherichia coli bacterium (Gram-positive), indicating a selective antimicrobial property of the samples. The variation of particle size employed in the experimental design of this study did not significantly influence the amount of incorporated $\mathrm{Ag}^{+}$ions obtained by AA analysis nor the inhibition halos obtained in the microbiological tests. Even so, the use of small glass particles in the ion exchange process is indicated. The ion exchange involves the contact between a solid phase and a fluid phase. The reduction of the particle size of the adsorbent solid leads to a greater area of contact between the phases and, consequently, greater incorporation of solute into the adsorbent solid [28]. The results showed that ion exchange can be effectively used to incorporate silver ions into glass microparticles and to develop antimicrobial material. An important factor in the development of materials with antimicrobial property is selective toxicity. A material toxic to human cells has its application reduced, especially in the field of medicine. The use of glass as a support for silver ions results in a slow and gradual release of these ions, avoiding the concentration of silver in the medium to reach levels toxic to humans and promoting the bactericidal effect over a long period of time. Biocides such as silver have numerous target sites on bacterial cells, being less likely to select resistant microorganisms. Silver has a bactericidal effect even at low concentrations (ppb) [29]. The application of silver glass as an antimicrobial material involves the treatment of surfaces, reducing the concentration of pathogenic microorganisms in hazardous environments, the addition of implants that will have contact with human tissues, the development of cosmetics and other products with antimicrobial properties.

\section{ACKNOWLEDGMENTS}

The authors wish to thank the Microbiology Laboratory, the Atomic Absorption Laboratory and Chemical Laboratory of the University of the Extreme South of Santa Catarina, UNESC.

\section{REFERENCES}

[1] P. Appendini, J.H. Hotchkiss, Innov. Food Sci. Emerg. Technol. 3 (2002) 113.

[2] M.A. Fiori, M.M.S. Paula, A.M. Bernardin, H.G. Riella, E. Angioletto, Mater. Sci. Eng. C 29 (2009) 1569.

[3] M.A. Fiori, M.M.S. Paula, E. Angioletto, M.F. Santos, H.G. Riella, M.G. Quadri, Mater. Sci. Forum 591-593 (2008) 362.

[4] E. Angioletto, "Desenvolvimento de processo de fabricação de cerâmicas com propriedades antimicrobianas", Un. Fed. Sta. Catarina, Florianópolis, Brazil (2003).
[5] M.A. Fiori, "Desenvolvimento e avaliação de compósitos do tipo polímero-madeira com propriedades biocidas", Un. Fed. Sta. Catarina, Florianópolis, Brazil (2008).

[6] S. Quintavalla, L. Vicini, Meat Sci. 62 (2002) 373.

[7] C. Catherine, J. Food Prot. 625 (1999) 474.

[8] "Antimicrobial plastics additives: trends and latest development in North America", Plast. Additives Compd. 4, 12 (2002) 18.

[9] J.P. Ruparelia, A.K. Chatterjee, S.P. Duttagupta, S. Mukherji, Acta Biomater. 4 (2008) 707.

[10] V.S. Dagostin, D.L. Golçalves, C.B. Pacheco, W.B. Almeida, I.P. Thomé, C.T. Pich, M.M.S. Paula, L. Silva, E. Angioletto, M.A. Fiori, Mat. Sci. Eng. C 30 (2010) 705.

[11] E.D. Freitas, A.C.R. Carmo, A.F. Almeida Neto, M.G.A. Vieira, Appl. Clay Sci. 137 (2017) 69.

[12] A. Chakravarti, S. Gangodawila, M.J. Long, N.S. Morris, A.R. Blacklock, D.J. Stickler, J. Urol. 174 (2005) 1129.

[13] D. Tien, K. Tseng, C. Liao, T. Tsung, J. Alloys Compd. 473, 1-2 (2009) 298.

[14] S. Ahn, S. Lee, J. Kook, B. Lim, Dental Mater. 25 (2009) 206.

[15] U. Jinu, M. Gomathi, I. Saiqa, N. Geetha, G. Benelli, P. Venkatachalam, Microb. Pathog. 105 (2017) 86.

[16] K.D. Secinti, M. Ayten, G. Kahilogullari, G. Kaygusuz, H.C. Ugur, A. Attar, J. Clin. Neurosci. 15 (2008) 434.

[17] U. Samuel, J.P. Guggenbichler, Int. J. Antimicrob. Agents 23S1 (2004) S75.

[18] B. Biškup, B. Subotić, Sep. Purif. Technol. 37 (2004) 17.

[19] S.A.M. Hanim, N.A.N.N. Malek, Z. Ibrahim, Appl. Surf. Sci. 360 (2016) 121.

[20] B. Noroozi, G.A. Sorial, J. Environ. Sci. 25, 3 (2013) 419.

[21] G. Özdemir, S. Yapar, J. Hazard. Mater. 166 (2009) 1307.

[22] S. Rangabhashiyam, N. Anu, M.S. Giri Nandagopal, N. Selvaraju, J. Environ. Chem. Eng. 2 (2014) 398.

[23] H. Perry, C.H. Chilton, Manual de engenharia química,

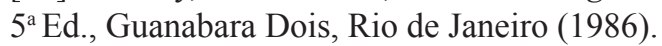

[24] S. Sugiyama, H. Matsumoto, H. Hayashi, J.B. Moffat, Colloids Surf. A: Physicochem. Eng. Aspects 169 (2000) 17. [25] A.C. Rios, C.G. Moutinho, F.C. Pinto, F.S. Del Fiol, A. Jozala, M.V. Chaud, M.M. Vila, J.A. Teixeira, V.M. Balcão, Microbiol. Res. 191 (2016) 51.

[26] J.-P. Blondeau, O. Véron, Opt. Mater. 34 (2011) 278.

[27] R. Dohrmann, Appl. Clay Sci. 34 (2006) 38.

[28] H. Han, Y. Cao, S. Chen, J. Lu, C. Huang, H. Zhu, P. Zhan, Y. Gao, Fuel 186 (2016) 750.

[29] N. Stobie, B. Duffy, D. McCormack, J. Colreavy, M. Hidalgo, P. McHale, S. Hinder, Biomater. 29 (2008) 963. (Rec. 24/11/2016, Rev. 11/04/2017, Ac. 15/08/2017) 